\title{
Corruption, Trust, Inclusion and Cohesion in North Africa and the Middle East
}

\author{
Roger Sapsford $^{1}$ (D) Gerasimos Tsourapas ${ }^{2}$. \\ Pamela Abbott ${ }^{3}$. Andrea Teti ${ }^{3}$
}

Received: 16 March 2017 / Accepted: 7 December 2017 / Published online: 26 December 2017

(C) The Author(s) 2017. This article is an open access publication

\begin{abstract}
Corruption provokes much anger in the Middle East and North African (MENA) and was important in the Arab Uprisings; it was government corruption that sparked the greatest anger among the population. The argument of this Report is (a) that corruption is a major and obvious breach of trust, (b) that the same is true for 'civil' corruption - 'wasta' in employment, business corruption - (c) that as well as not trusting their government and its institutions, MENA residents do not trust each other either, to the detriment of maintaining functional nation states without coercion, and (d) that corruption is a special case of breach of the Rule of Law which is essential for a decent society. The initial focus on corruption leads to consideration of what people think they can reasonably expect from government and from each other. Ultimately, corruption divides the society into those who extort bribes or dispense favours and those who are required to pay bribes and are excluded from favour - in other words, there is a breakdown of social inclusion. Further, it destroys trust between people and trust in social institutions, which breaks the cords that hold modern societies together - it is an attack on social cohesion. The article is based mainly on the Arab Transformations Survey, carried out in six developing MENA countries in 2014, three years after the 'Arab Spring'.
\end{abstract}

\section{Roger Sapsford}

Gerasimos Tsourapas

g.tsourapas@bham.ac.uk

Pamela Abbott

P.abbott@abdn.ac.uk

Andrea Teti

a.teti@abdn.acuk

1 Aberdeenshire, UK

2 University of Birmingham, Birmingham, UK

3 University of Aberdeen, Aberdeen, UK 
Keywords Corruption · Trust $\cdot$ Rule of law $\cdot$ Social inclusion $\cdot$ Social cohesion $\cdot$ MENA

\section{Introduction}

This article is based on a survey of attitudes and opinions carried out in 2014 in six countries of the Middle East and North Africa, with a representative sample of more than a thousand-people aged 18 or older in each country, plus other similar surveys and official statistical series. The survey was carried out three years after the wave of uprisings across the region sometimes described as 'the Arab Spring', and it explores what respondents remember as driving the uprisings and the extent to which the concerns of 2011 are seen as having been answered by 2014. The article examines how living with corruption damages trust in government and social institutions and its influence on social inclusion and social cohesion - in other words, the extent to which it undermines the nation state. Rather than engaging with past debates in economics and political science it works within the more sociological framework of the Decent Society model (Abbott et al. 2016) and is concerned with corruption's effects on key social processes which sustain nation states and make it possible for them to offer a decent life to their inhabitants.

\section{The Conceptual Framework for Considering Corruption and Trust}

Corruption has traditionally been approached as a fundamental but in essence bounded or separate problem impeding the onset of democratisation (see e.g. Bellin 2002). Where there are higher levels of corruption residents express a more negative evaluation of the performance of the political system and lower levels of trust in civil servants (Anderson and Tverdova 2003), and corruption reduces the perceived and functional legitimacy of the nation state:

independent of socioeconomic, demographic, and partisan identification, exposure to corruption erodes belief in the political system and reduces interpersonal trust (Seligson 2002).

In this article we are more inclined to see corruption as both a cause and a manifestation of fractures within the fundamental processes which bind together and legitimate the nation state, using the conceptual framework elaborated in The Decent Society (Abbott et al. 2016). The Decent Society Model, like the Social Quality Model on which it was based, posits four broad classes of social process which hold a society together and have the potential to make it into a decent place in which to live. These are

- economic security (the possession of sufficient resources and being able to count on support in life-course stages during which resources run short (parenthood, the education of children, old age, etc.) and during sudden reversals of fortune (e.g. ill health, loss of paid employment., bereavement),

- empowerment (having the knowledge, resources and institutional infrastructure to fulfil one's capabilities), 
and the two with which we are most concerned in this article, Social Inclusion and Social Cohesion.

- Social Inclusion is quite simply the extent to which all residents in a society count as full members of it; we often use gender as a case in point, as in many societies women are second-class citizens, if indeed not treated predominantly as children, slaves or property, and do not have the same rights as men, in theory and in practice.

- Social cohesion is what holds a society together and permits it to function and develop as one common 'work in progress' as opposed to a forum for competing interests. It involves the absence of groups who face discrimination and feel excluded, but it also supposes a shared discursive environment within which one can assume that people will treat others fairly, the power of the state and the rich neighbour will be constrained by the rule of law and, in general, 'the rules' will be respected.

Fundamental to understanding this discursive environment is the concept of trust.

At one level, trust is a feeling of confidence in those around you and/or in things unseen - in the abstract 'other people' who are not named or visualised but whose assumed reliability underlies transactions outside the sphere of immediate family and friends. It is also a cognitive state, the perception of socioeconomic and sociopolitical systems and relations as regularities on which one may depend. (Sapsford et al. 2015)

It has been seen as prerequisite for the functioning of democratic institutions (e.g. Almond and Verba 1963) or of market economics (e.g. Raiser 1998), or indeed for the exercise of agency in complex societies (e.g. Sztompka 1999). The breakdown of trust has injurious effects on investment (Habib and Zurawicki 2002), social inequality (You and Khagram 2005) and the perceived legitimacy of the state (Kaärinen 2007).

We argue in this article that the extent of state corruption and the failure of trust in government and in people in general which is experienced in MENA have worked together to damage the processes of social inclusion and social cohesion which normally maintain a functional unity across the nation.

\section{Sources of Information}

The main source of data for this article is the Arab Transformations survey carried out in 2014 in Egypt, Iraq, Jordan, Libya, Morocco and Tunisia as part of the EU Arab Transformations project. Adults aged 18 or older were the target population.

The precise details of sampling method differ between countries, depending on demographic and administrative structure and political history. In each country multistage selection of primary units led to random or quasi-random ('random route') selection of households and random selection of a person (alternatively male and female) as respondent. Samples were stratified by geographical region where this had demographic implications and by average affluence and urban/rural location within district if there were marked differences. Random selection of respondents within 
households aimed at ensuring representation by evening out other potential differences between respondents, such as age. Sizes of achieved samples varied from c. 1250 in Tunisia to c. 2150 in Jordan and depend, again, on local conditions. Data were collected by interviewers trained and supervised by the local partners. Detailed information will be found in the Project Handbook (Abbott et al. 2017).

Two other surveys have been used where their questions covered different ground or made finer distinctions. Wave 3 of the Arab Barometer was carried out in 2013 in all six countries. Round 6 of the AfroBarometer took place in 2014/15 and yielded data for this article on Egypt, Tunisia and Morocco. The AfroBarometer sampled around 1200 in each country and the Arab Barometer were mostly around 1200 except in Jordan, where nearly 1800 were sampled. Both aim for representative sampling and used broadly similar strategies to those of Arab Transformations to achieve this; the details of methods may be found through the respective websites, listed under 'Surveys and databases' in the References section below.

We have also drawn on Transparency International's Corruption Perceptions Index, the World Bank's Enterprise Surveys and World Development Indicators and Global Financial Integrity's Illicit Financial Flows. Again, website addresses will be found in the list at the end.

\section{Corruption in Mena Countries}

People across the whole of the Middle East and North Africa Region (MENA) see their countries as thoroughly corrupt, and they are deeply disillusioned by it. It is mentioned as a major reason for the 2011 uprisings, for example. The Arab Transformations survey asked for the most important reasons why people went on the streets (allowing them to name two from a list), and while differences between countries are significant, protesting against corruption is nominated by between 41 and $64 \%$ of respondents; it is the most popular reason by far in four of the countries, and while it falls below 'economic problems' in Egypt and Jordan, it is chosen by far more people than any of the remaining choices (Fig. 1).

We have not attempted to construct a total measure of corruption in all its forms; it makes better and more interpretable sense to disaggregate (Heath et al. 2016). This section covers (a) respondents' perception of the amount of corruption in their country and what the government is doing about it, (b) 'private-sector corruption, ranging from payments by individuals to secure preference within or even access to public services (e.g. health or education), through the extent of payments and 'presents' by companies to obtain permits or shorten bureaucratic delays, up to large-scale illegal financial transfers, and (c) the fraudulent elements of 'crony capitalism'.

\section{Corruption in Government}

The Transparency International Corruption Perceptions Index, which averages a number of international surveys, indicates a high level of government corruption in all six countries in 2011, ranging from a score of 45 for Jordan, which ranked 56th best out of the 183 countries, to Iraq and Libya, with scores of 20 and 18 respectively and ranking 175th and 168th. In 2014 the scores and the rankings were very similar. The World Bank's Enterprise 


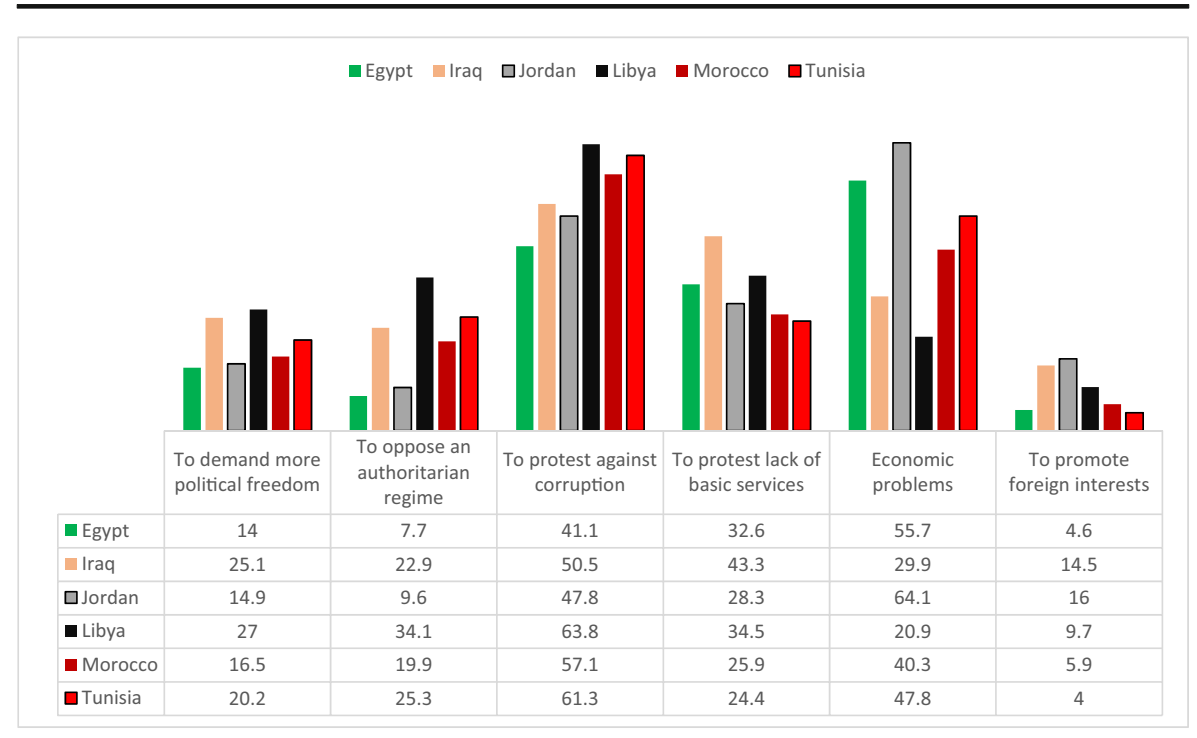

Source: ArabTrans Survey (fieldwork conducted in 2014)

Note: all differences between countries in this article are significant at $p<0.001$, using $\chi^{2}$

Fig. 1 Reasons for taking to the streets in 2011 (\%)

Surveys identify the giving of 'presents' to government officials to secure contracts or in general to 'get things done' as the specific form of corruption most frequently named by businesses based inside or outside the country (the percentage mentioning them approaches $40 \%$ on average in MENA countries), but bribes or presents were also used to obtain other licences and permits, to get access to electricity or water and in meetings with the tax department, by over $10 \%$ of reporting businesses and often over $20 \%$.

The Arab Transformations Survey asked respondents to assess the amount of corruption to be found within state institutions in their country at present (2014) see Fig. 2. Here the most noticeable thing is that virtually no-one said there was no corruption in government, except in Libya. At the other extreme, around $60 \%$ in every country seemed to think that there was a great deal of it.

The AfroBarometer, Round 6 of which ran in 2015, covered only Egypt, Morocco and Tunisia among our countries but has questions which permit us to look in much finer detail at government corruption within them.

- Egypt, for example, was more trusting of government - about 30\% said there was no corruption among the judges and magistrates, for example, compared with $2.4 \%$ in Morocco and 16\% in Tunisia; 29\% thought most or all were corrupt, however lower than Morocco's 35\% but higher than Tunisia's $13 \%$.

- In fact the Egyptians who thought that most or all were corrupt stood at between 35 and $45 \%$ in all categories - the President's/Prime Minister's Office, local government counsellors, police and tax officials.

- Morocco was similar.

- Tunisia believed there was substantially less corruption in the Offices of the President and Prime Minister, as well as tending to think that the judges were relatively uncorrupted. 


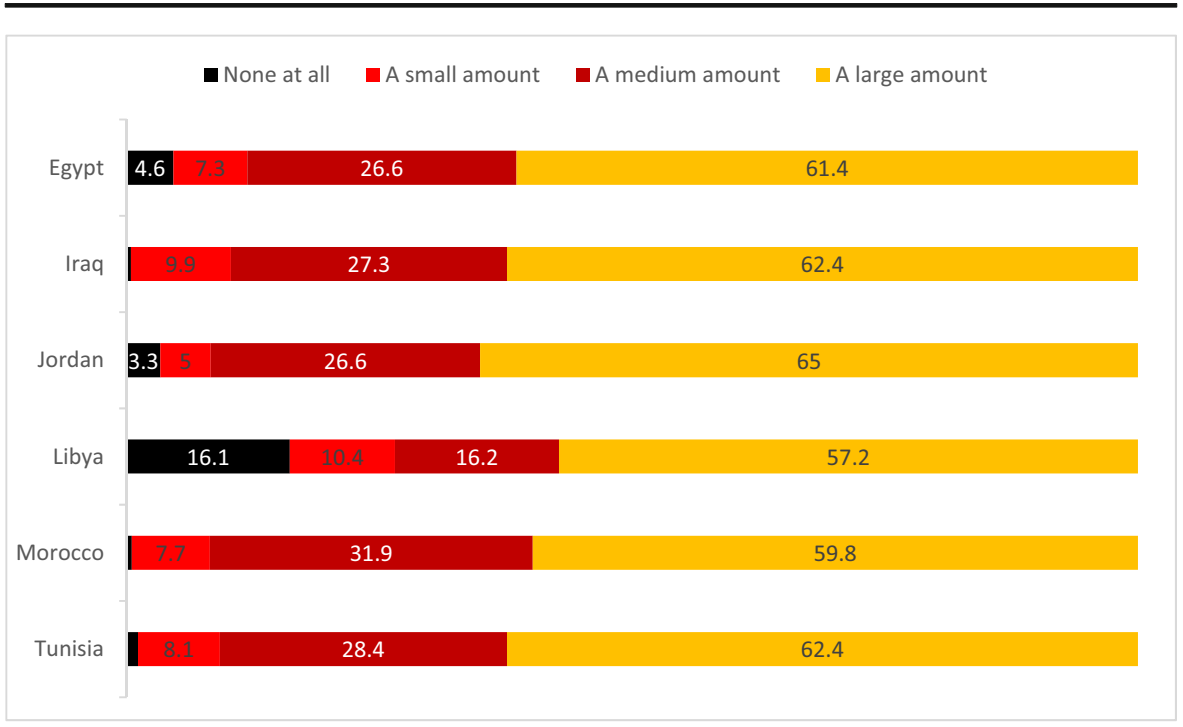

Source: ArabTrans Survey (fieldwork conducted in 2014)

Fig. 2 Extent of corruption in state institutions and agencies of the country

- Eight per cent of Egyptians thought there was no corruption in Parliament and only $2 \%$ of Moroccans. In both countries over 35\% thought most or all elected politicians were corrupt, but $18 \%$ of Tunisians thought there was no corruption among them and only $16 \%$ thought most or all were corrupt. Three quarters of the Egyptians and Moroccans had never been offered an election incentive, but this leaves a quarter who had been offered one, while in Tunisia over 95\% said they have never been offered an incentive.

A crack-down on corruption is one thing that rulers mostly promised at the time of the Arab Uprisings - it is an easy rhetorical gesture - so we asked whether our respondents felt, three years after the Uprisings, that such a crackdown had taken place. The simple answer is that they did not: over half of the respondents thought that little or nothing was being done (Fig. 3). Even in Egypt, the country where people perceived their government's efforts in the most positive light, more than a third of respondents thought little or nothing was being done. In Morocco and Jordan this rises to over half, and in Iraq, Tunisia and Libya it approaches two thirds.

\section{Corruption in the Private Sector}

Corrupt practices may be extortions from 'ordinary people', or they may favour some people over others for jobs or rewards on grounds other than capability and suitability. Payment for basic services - the requirement to make a payment, to pay a bribe, in order to get medical or household or school services or to avoid a problem with the police - is a straightforward charge on the private citizen's purse. In the AfroBarometer, $35 \%$ of Egyptians said they had paid a bribe at least once, and 36\% of Moroccans, but only $7 \%$ of Tunisians (and mostly for medical treatment). Overall, 19\% in the three 


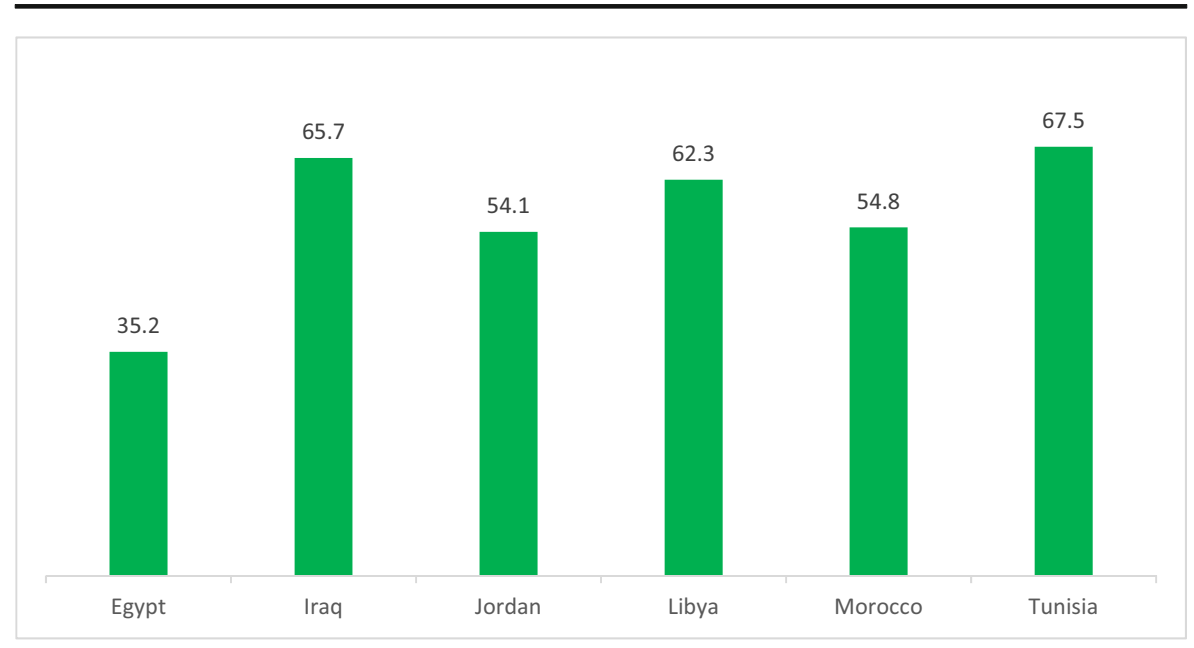

Source: ArabTrans Survey (fieldwork conducted in 2014)

Fig. 3 Percentage who thought government was doing little or nothing to crack down on corruption

countries paid for medical services, $11 \%$ to avoid trouble with the police, $9 \%$ for household services (water, sanitation etc.) and $7 \%$ for school services; the pattern by country is shown in Fig. 4a. The burden of bribery is falling more heavily on the poor than the more affluent (Fig. 4b): those in Egypt who have ever gone without some basic necessity in their lives are somewhat more likely than those who have never done so, and in Morocco and Tunisia they are more than twice as likely to have paid a bribe.

Corruption may also consist in bribes levied from businesses, and particularly new or expanding businesses, as the price of a government department doing its routine job and issuing documentation, as was discussed in the previous section. This is not a new thing but has been endemic for a considerable time. The bribe or 'present' may be necessary to obtain service at all, or as an inducement for faster service, or in order that the strict provisions of laws or regulations might be relaxed in particular cases.

Further unbundling is needed to clarify the specific problems and challenges confronting various governments and the individual agencies and departments within them. Do the fundamental challenges involve extortion in tax collection? The deliberate misrepresentation of standards in bid documents? Collusion in pharmaceutical procurement? ... The payment of "speed money" for permits and licenses? Pressuring companies to take on a well-connected silent partner to facilitate private investment? The Arabic language itself reflects this diversity and has devised a number of terms to address various problems, ranging from bakshish (small facilitation payments) to wasta (connections) to fassad (corruption or "rot"). Interestingly, many of these terms can also have neutral and less pejorative connotations. (Beschel 2008)

In other words, some of this is seen not as criminal acts (though it may be acknowledged that they are against the law) but rather as payment for additional services or a small venial surcharge on the provision of services - analogous to the 'tipping system' 
Fig. 4 Bribes paid for 'ordinarylife services' and affluence of those paying.

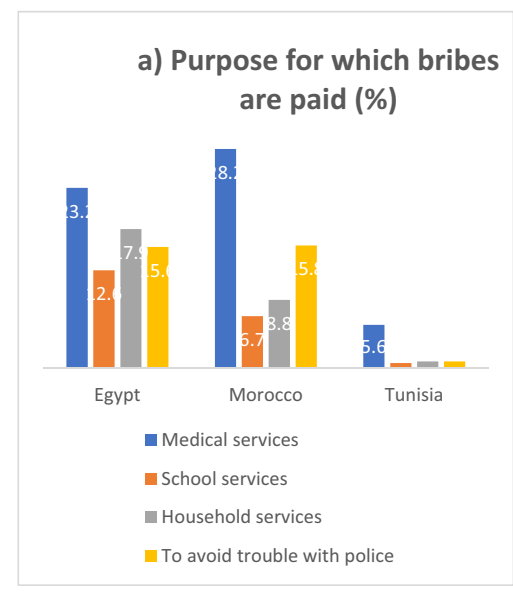

b) \% paying bribes, by affluence

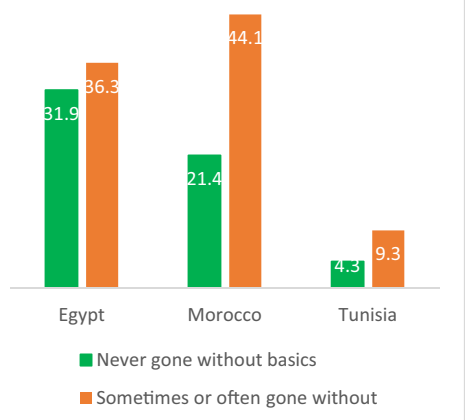

Source: AfroBarometer Round 6 (Fieldwork: Tunisia - 2014; Egypt, Morocco-2015)

In Figure 4b the 'basics' considered are food, water, cooking fuel, medical care and a cash income.

of the developed North and West. Judging by the answers given to the World Bank's Enterprise Surveys, it is a matter of normal business procedure for both domestic and external concerns (that is, the proportion reporting having done so is in double figures in MENA countries in many years) to pay a bribe in order to receive an operator, import or construction licence/permit, presents are taken to the tax office by often a quarter of respondents, and incentives to government departments to speed and smooth procedures seem also not to be uncommon.

Fraudulent accounting at an international level is also common; money is spirited out of the country by straightforward fraudulent transfer or by varieties of misinvoicing, in large amounts. Figure 5 gives estimates calculated by Global Financial Integrity of the extent of illicit financial outflows in the years 2004-2013. The main thing to note here is that this kind of corruption is very expensive for governments: the amounts frequently correspond to at least $5 \%$ of GDP; the highest was more than $15 \%$ (Iraq in 2010). In 2013 the highest were Jordan (10\%) and Iraq (7\%) and the lowest Egypt (1\%), with the others amounting to $3-4 \%$. 


\begin{tabular}{|c|c|c|c|c|c|c|c|c|c|c|}
\hline 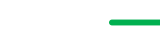 & Egypt & Iraq & 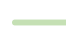 & rdan & Lib) & & Morocco & 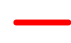 & unisia & \\
\hline & 2004 & 2005 & 2006 & 2007 & 2008 & 2009 & 2010 & 2011 & 2012 & 2013 \\
\hline Egypt & 4.10 & 5.69 & 4.23 & 3.69 & 3.75 & 0.00 & 0.98 & 2.22 & 1.81 & 1.27 \\
\hline$\Longrightarrow$ Iraq & 0.00 & 0.00 & 0.00 & 4.12 & 14.68 & 14.62 & 15.24 & 7.63 & 6.62 & 6.88 \\
\hline Jordan & 7.67 & 10.53 & 6.40 & 5.36 & 5.40 & 5.42 & 6.18 & 6.13 & 6.15 & 10.00 \\
\hline Libya & 0.00 & 3.06 & 0.00 & 0.00 & 2.01 & 0.00 & 2.86 & 0.00 & 4.25 & 4.59 \\
\hline Morocco & 5.04 & 8.83 & 4.78 & 5.22 & 5.84 & 3.97 & 3.75 & 4.00 & 4.60 & 3.67 \\
\hline Tunisia & 3.61 & 3.03 & 3.89 & 4.31 & 5.19 & 4.72 & 3.92 & 3.56 & 4.43 & 4.31 \\
\hline
\end{tabular}

Source: Global Financial Integrity data

Note: values of zero should not necessarily be believed; they may indicate simply a lack of information.

Fig. 5 Illicit financial flows from the six MENA countries (\$US billion)

Probably even more pervasive than bribes at the level of the ordinary citizen is the practice of 'wasta'. Wasta (the equivalent of the UK 'old boy network' of those who went to a small number of prestigious schools) is the practice of preferring family, friends and people with whom one is in some kind of personal relationship or at least recognises as 'one of us' or 'our sort of person', when it comes to awarding jobs, promotion, bonuses, pay increases, positions of responsibility or honour, university places etc. Its effect is that who you know, or more broadly the recognition of your ingroup status, is more important and more valuable than what you know or what you can perform. It is firmly and widely believed in the MENA countries that wasta is what gets you employment and, mostly, that no route which does not involve wasta will do so. While wasta is found in the highest reaches of society, it is also found at very basic levels of jobs and qualifications; it is seen as an essential for getting jobs on the docks or the building sites, as well as leading to preferment within government and the army. Asked in the Arab Transformations survey whether wasta played a role in employment (Fig. 6), there are significant differences between the sample countries but the overall picture does not vary much. Between half and three quarters said it was extremely widespread, depending on the country, and only a very few (ranging from $0.9 \%$ in

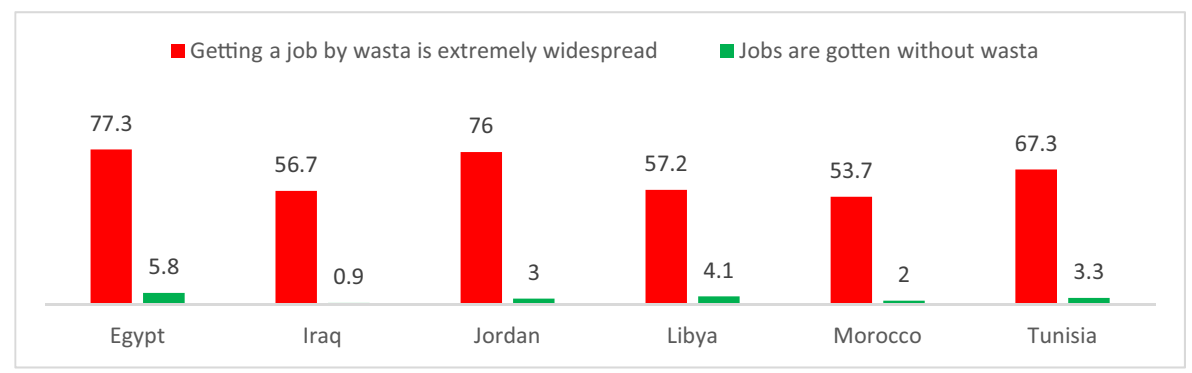

Source: ArabTrans Survey (Fieldwork: 2014)

Fig. 6 The need for wasta when seeking employment (\%) 
Jordan to $5.8 \%$ in Egypt) said it was possible to get work without it. The Arab Barometer's more elaborate and precise formulation of the same question elicited very much the same answers.

\section{Crony Capitalism, or Government Wasta in Business}

Over and above these corrupt acts or requirements, we need also to consider the more systemic ways in which corruption has become structured into the MENA states. There are reasons to suspect that perception indices such as the Corruption Perception Index, cited above, are weighted towards petty corruption and may not adequately reflect broader problems of "state capture" or the use of state machinery to direct economic rents to favoured parties - a problem many sophisticated observers have argued is particularly acute in some MENA countries (Beschel 2008).

The reform of central economic control in the MENA countries outlined by Abbott and Teti (2016) was supposed to bring about an economic structure based on a strong private sector independent of government and therefore to some extent independent of national politics. However, what happened in practice was something rather different. The required reforms entailed privatisation of the 'spoils of government', but the redistribution of rents away from government control - which in the MENA countries did not necessarily lead to a developmental patrimonialism (see Booth and Golooba-Mutebi 2012) but rather to the more common patrimonialist strategy of reward of allies and 'buying off' powerful opposing forces - did not necessarily lead to capital being invested within the country. Before structural adjustment was forced on them in the 1980 s these countries had a 'political settlement' or 'social contract' whereby the middle class (and working class) accepted authoritarianism in exchange for decent job (public sector employment), decent social services and fuel and food subsidies. It was the breakdown of this contract well before 2011 that eventually became the main driver of the Uprisings (Abbott and Teti 2016, 2017), and things have not changed a great deal since then.

The distortion of this transformation most commonly practised in the MENA countries (and in many other places) was to create friends and allies as 'independent concerns' which then continued to work closely with government and to follow political rather than economic agenda. The main driver is political; those in power work mostly to maintain their position at all costs. The industrial, commercial and financial leaders become an intrinsic part of the government elite or, worse, members of the government elite become the industrial, commercial and financial leaders without thought to their qualification and suitability. The transformation has been expensive for the middle classes across the region (Hanieh 2013; Richards et al. 2014) in terms of decent jobs and also in terms of opportunities to establish industrial or commercial concerns. It is tied up with the loss of government employment with privatisation and the failure of the crony capitalists to invest in enterprises that created employment. Also, the crony capitalists tended to be given favoured access to bank loans, making it virtually impossible for non-favoured enterprises to get them. This had a knock-on effect on the potential of small- and medium-sized enterprises to grow and create employment. 
Difficulties emerge, if there is a need for foreign capital or even inside investment, when politics is the driver of economics and the economy is run for political ends. Governments are responsible for the regulatory framework, and all too often this kind of cronyism leads to favourable operating rules for the cronies - or, indeed, little or no regulation that is binding on them - while new capital from outside faces barriers to entry and does not have equal access to the markets. There were barriers to foreign direct investment in all the countries, but at least in Egypt a significant proportion of the crony firms do have foreign investment, mainly from the Gulf states. The FDI went into the oil and gas sectors and real estate, however, which did not create sufficient decent jobs or increase the proportion of GDP from manufacturing; oil and gas generated rents for government but mostly acted as a mechanism for exporting capital in the form of profit. There was an increase in tourism, but this is rent income and precarious (as indeed are the prices of oil and gas).

Even if it is not the case that rents are devoted to fostering the welfare of state elites and their followers and clients, political aims (e.g. GDP growth, increase in taxation revenues) generally take precedence over attracting and keeping capital investment and creating jobs for citizens. This is the opposite of what has normally formed part of IMF-driven 'structural adjustment', which involves the shift of regulatory power from its monopoly position in the hands of government to agencies which are to some extent independent of government.

An important political dimension of the reform package has been the delegation of substantial regulatory rule-making and enforcement power from .. ministerial departments to .. independent regulatory authorities. ... Delegation of rulemaking authority ... [was] meant to reduce the discretionary powers of the political authority and attain a more rule-based and transparent framework for economic policy. .... Replacing direct and often discretionary state control with new forms of control through rules and procedures corresponds to a major realignment in the structure of the state and in the way state power has been deployed (El Atiyas 2014).

It is this realignment of the state and extension of the 'rule of law' that fails to take place if those subject to regulation are allies of government and a part of the political as well as the industrial/ financial elite.

Corruption is bad for business because it adds costs to production, like an extra layer of tax. It is bad for business people because it adds delays and uncertainties to the business process and makes the task of setting up to make things or sell them or provide services riskier and more uncertain, less predictable. (Beyond this, there are the extra costs of the non-favoured non-crony firms, which mean that their products are not competitive on export markets.) It is bad for residents in general because not only does it cost money they may not be able to afford and decrease the predictability and hence the security of their lives, but it sends a message about where they stand in their society and what its 'rules of engagement' are. 


\section{Corruption, Social Inclusion and Trust in Government}

Corruption may fruitfully be seen as a special case of breaching the Rule of Law, by which is meant not just the laws (regulations, directives) themselves, nor even their implementation, but a way of structuring the socio-political order to maximise social inclusion and social cohesion. Social cohesion we shall consider in the next section of the article. Social inclusion - being a full member of a social unit - is what emancipates and empowers us, side-stepping the suspicion that our lives are governed by and for some other group.

A fundamental principle of the rule of law, as generally understood, is that all are equal before it and no-one stands outside it. This means that everyone is recognised as a full member of the society. There are no groups that are excluded (with some careful arguments about infants and children, very old people and those who are sick, disabled or mentally impaired, which generally involves the concept of Human Rights as in some sense 'belonging' to members of a society even if they are in no position to assert or claim them). It also means that there is no-one who stands outside and above the law; our rulers are subject to the same rules as the rest of us. Corruption breaches the rule of law because some people are able to take the right to extort from or control others, for their own enrichment or advancement or even amusement, and there is no easy way to stop them doing this.

One might say that the corrupt society has two classes of people: a superior class that demands bribes and an inferior class that pays them, and/or an elite or a set of intermediate functionaries that dispense favours and an inferior group that is excluded from them. The superior class effectively stand above the law, at least in this respect, which brings both law and government into disrepute (see Fig. 9 below). This would be an over-simplification, because those who extract bribes may in turn be faced with the need to pay bribes or pay for favours further up the social/political hierarchy ${ }^{1}$ - there is no simple fracture into two distinct 'classes'. However, all payers of bribes are alike in this respect, that the action brings to light their lack of control - they are second-class citizens within their socioeconomic environment - and demonstrates to them that they cannot count on the rule of law. In the words attributed to Giovanni Giolotti, a longserving Prime Minister in Italy around the turn of the twentieth century, "Laws are applied to enemies but only interpreted as regards friends".

The MENA countries, even the oil-rich ones with some spare financial capacity, are not good at social inclusion. The Arab Barometer is a useful source here, asking several questions which are not asked in the Arab Transformations Survey, or not in as useful a form. In none of the six countries does the it show as many as $15 \%$ who think they are largely treated in the same way as everyone else (Fig. 7). At least 13\% in Iraq, and up to twice that number in Egypt, think they are not treated in this way at all. (There is no particular demographic pattern or grouping underlying these responses.) It is also clear from responses to questions in the AfroBarometer ( 2015) that the President is above the law, at least in those countries which the survey covers. While most agree that it is Parliament that makes the laws, not the President (or King, presumably, in Morocco), around half in Egypt and Morocco and a third in Tunisia think he is free to act rather than having to obey laws and the courts, and over $80 \%$ in all three countries say that he

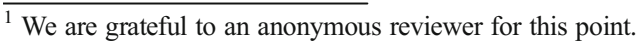




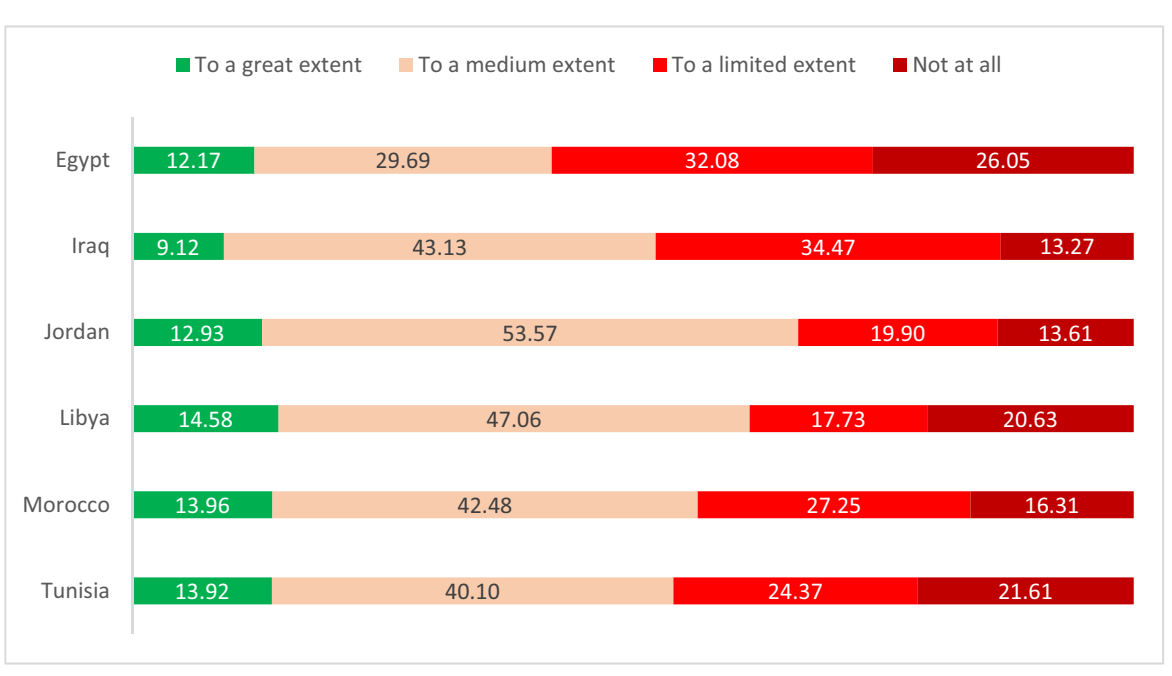

Source: Arab Barometer Wave 3 (Fieldwork: Iraq - 2012-13; Egypt, Jordan, Tunisia - 2013; Morocco - 2013-14; Libya - 2014)

Fig. 7 Extent to which respondents feel they are treated equally with others (\%)

ignores parliament and the laws at least some of the time (or do not know whether he does or not).

Asked about what was important in their Constitution (and Egypt, Libya and Tunisia were in the process of rewriting theirs at the time of the survey), over half the Arab Barometer respondents thought it was very important to have a formal separation between the executive and the legislature (or just under half in Jordan and Morocco, the two monarchies) and over $60 \%$ felt it very important that the power of the head of state be limited (except in Jordan, where the figure was only 35\%). Fewer than $6 \%$ thought the first of these as not important at all and fewer than $7 \%$ the second (except in Jordan, where $13.6 \%$ said the limitation on power was not at all important) (Fig. 8).

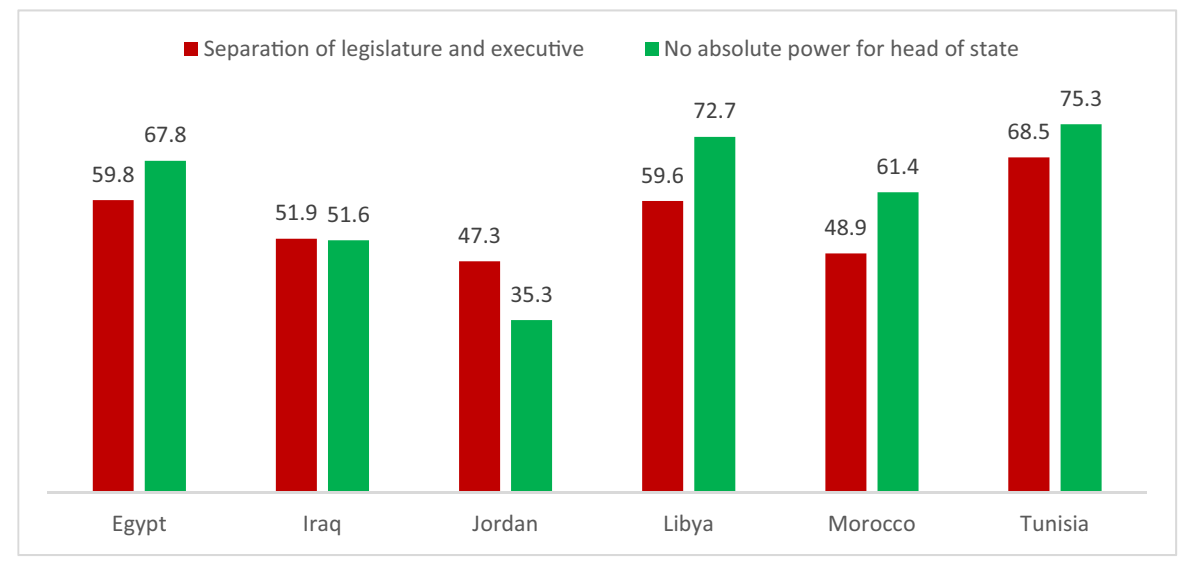

Source: Arab Barometer Wave 3 (Fieldwork: Iraq - 2012-13; Egypt, Jordan, Tunisia - 2013; Morocco - 2013-14; Libya - 2014)

Fig. 8 Limits to power of head of state, desirable in the Constitution (\% agreeing) 
Corruption may be thought of as individuals, groups or elites giving themselves powers and rights that are not extended to the rest of the society. Around $90 \%$ of the Arab Transformations Survey respondents think there is strong corruption in state agencies and institutions (Libya is a little lower, at 73\%), and between a third and $45 \%$ think the state is doing little or nothing to eradicate it. Where we have the detailed information (from the AfroBarometer) we find that between 13 and 35\% think all or most of the politicians, the tax officials and even the judges are corrupt. Bribery reaches down beyond the business world to condition even such transactions as the use of a supposedly free health service. Wasta is also very influential in the allocation of jobs, and if you do not know the right people and are not known by them you will have difficulty finding a job, which is profoundly divisive. 'Crony capitalism' may be seen as a high-level governmental version of the same process, with business opportunities and advantages reserved for the friends of government. The result is that there is little trust in the Government (Ministers), Parliament (elected representatives) or local government and even a fair amount of distrust of the police and the courts (Fig. 9). Corruption destroys trust in the institutions of government and the overall Rule of Law - whatever the laws, the social practice oppresses some in favour of others and symbolises their exclusion from the core of their own society.

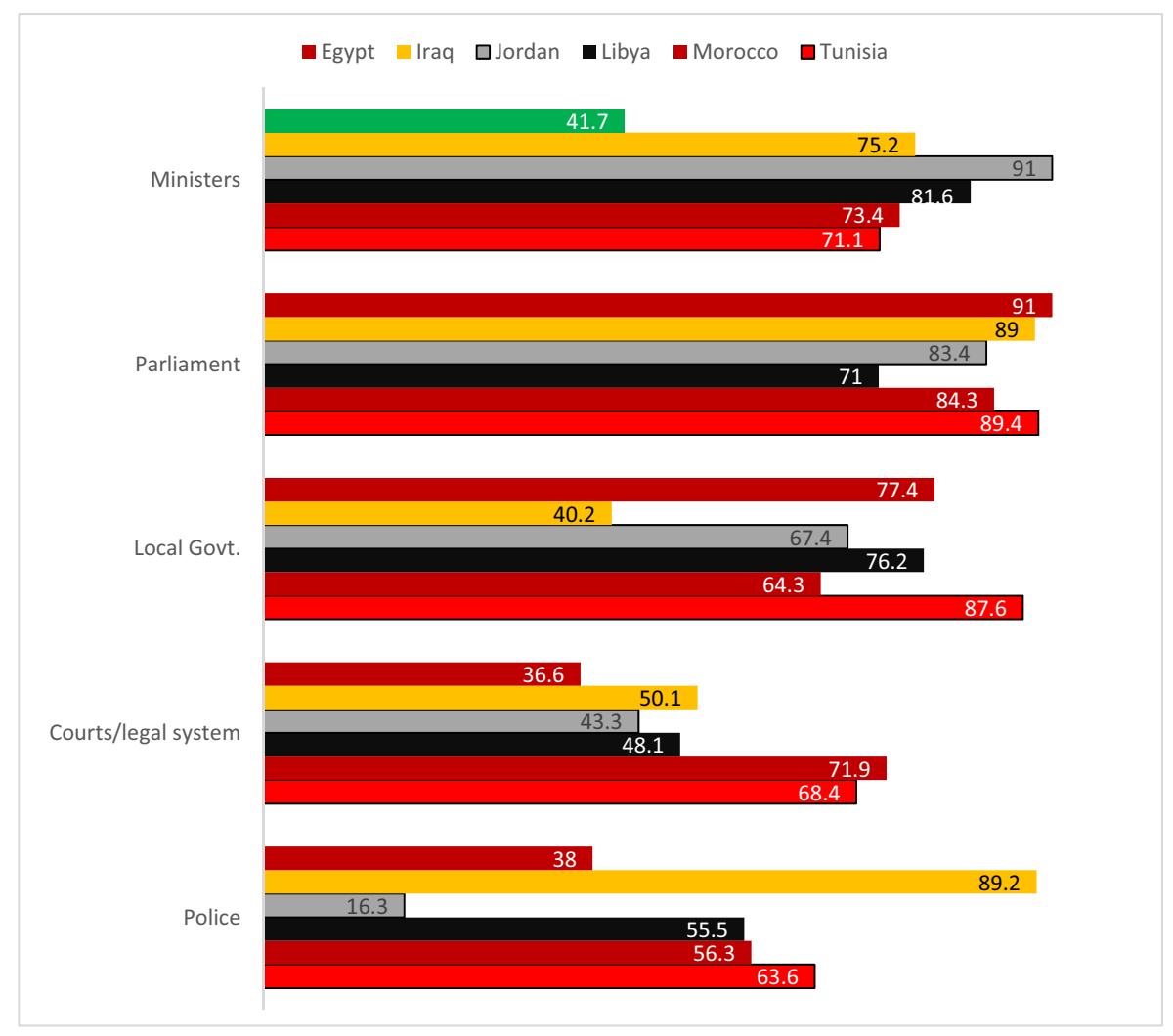

Source: ArabTrans survey (Fieldwork: 2014)

Fig. 9 Percentage expressing little or no trust in aspects of government 


\section{Trust and Social Cohesion}

To the extent that people are and feel included in their society, what maintains this situation is social cohesion, characterised at its simplest as 'shared norms and values'. This does not mean that culturally different groups or those structurally positioned with different interests will necessarily value the same goals or take the same things for granted about the society in which they live. Modern societies persist through what Durkheim (1893) called organic solidarity, rather than the mechanical solidarity of literal equivalence, and diversity is possible and perhaps necessary in a modern society. Specifically, what needs to be shared it is a 'discourse' that embodies a common understanding of 'the rules of the game' - how social relations are managed and disputes resolved in such a way as to provide a fair and equal solution irrespective of position in the society. This is a principle to be applied without exception in a fully cohesive society, an approach which is taken for granted, 'goes without saying' and is the automatic, default approach to both personal and institutional interaction. However, acceptance of this principle in practice requires trust that institutions will function even if we do not have personal knowledge of the people who run them and therefore a great deal of trust in persons unseen. That those whom we identify as bearers of social roles will act 'in role' rather than following their own or their group's interests exclusively is what keeps the banks working, what underlies both commerce and the labour market, what makes bureaucracy function and what makes the laws of the land a common possession rather than a set of rules imposed by a ruler or ruling elite. Law may favour the rich and powerful, but it is also, as Robert Bolt has Sir Thomas More explain in A Man for All Seasons, all that the little people have to hide behind when powerful winds blow.

There are signs that at least an understanding of what is required for cohesion underlies the disaffection. In the three countries covered by the AfroBarometer for this period, over $80 \%$ in Egypt and over $90 \%$ in Tunisia agree that the decisions of the courts are binding on all, for example, and that people must obey the law (but 64\% and $71 \%$ respectively in Morocco, a majority but not approaching unanimity at all closely). Around $80 \%$ agree, similarly, that people must pay their taxes in Egypt and Tunisia, and $67 \%$ in Morocco. So the fundamentals of the Rule of Law - that laws must be obeyed by everyone equally and the decisions of the courts are binding on everyone equally - would appear to have a place in MENA discourse about government.

However, a lack of social cohesion is reflected in the figures for trust in 'other people' in general and in the abstract - persons unseen or unknown. In the AfroBarometer (Fig. 10), $70 \%$ or more choose 'you cann't be too careful' rather than 'most people are trustworthy', in the three countries for which it provides data for this article. There are strong signs of the 'retreat into the local' which typically replaces trust in wider social institutions (Sapsford et al. 2015); people are much less distrustful of neighbours, people know to them and, above all, the family. Arab Transformations figures are similar, for the proportion expressing little or no trust in the 'anonymous other'. There is a little more trust in the organised institutions of civil society, and perhaps in the truthfulness of the media in some countries, but even religious leaders are not fully trusted: around half of the respondents said they had little or no faith in them in Egypt and Iraq and substantially more in the other countries (Fig. 11). Among other things, trust is a behavioural intention - to expect the behaviour of others to 


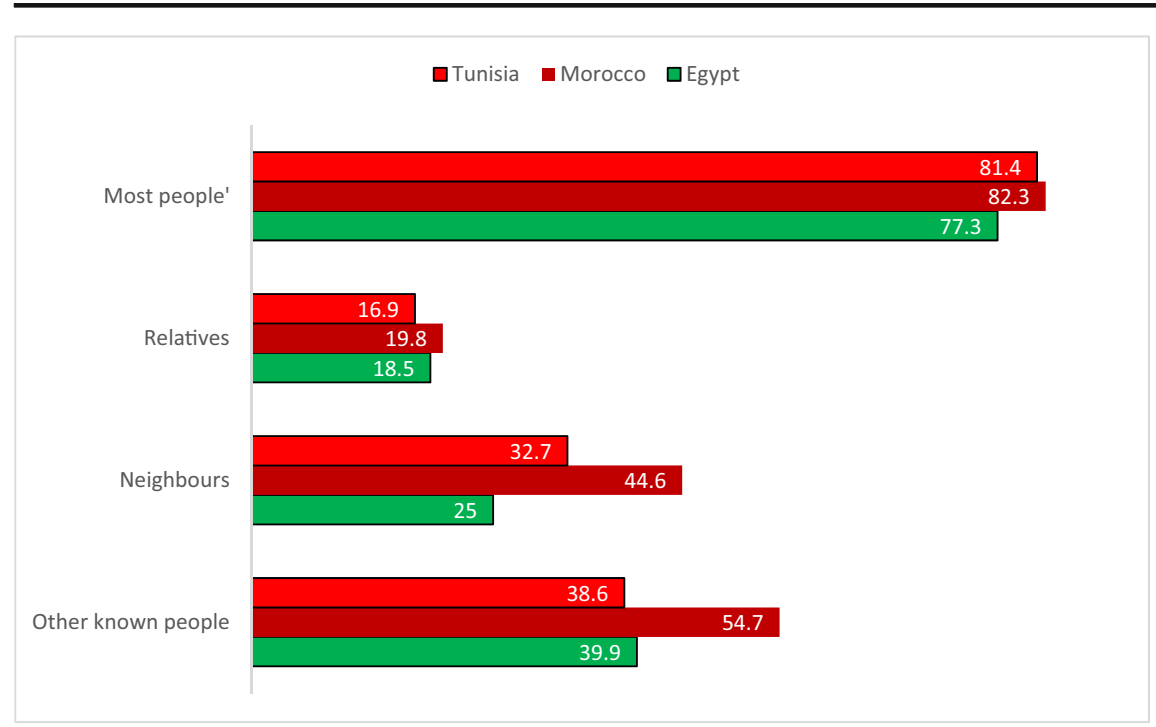

Source: AfroBarometer Round 6 (Fieldwork: Tunisia - 2014; Egypt, Morocco - 2015)

Measured: 'most people': 'must be very careful' (as opposed to 'most people can be trusted') Others: 'no' or 'just a little' trust

Fig. 10 Local and general distrust $(\%)$

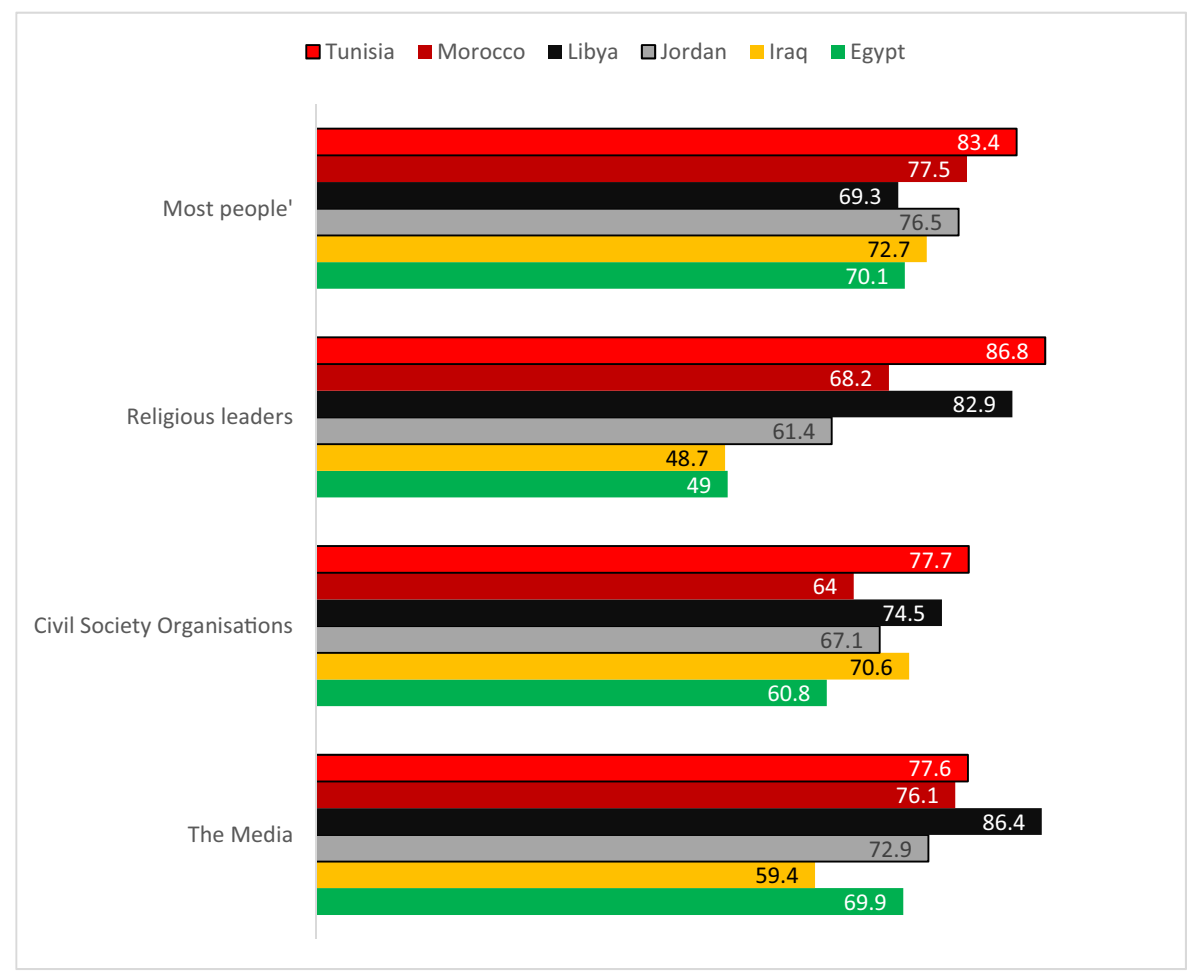

Source: ArabTrans survey (Fieldwork 2014)

Measured: 'most people': 'most people are not very trustworthy'. Others: 'no' or 'not very much' trust.

Fig. 11 Distrust of 'the other' and of non-governmental institutions

\section{型 Springer}


express the purpose of a social institution rather than the interests of a faction, and to expect in one's turn to seek mutual rather than individual/factional satisfaction. To achieve this, insight into the other person's/group's norms and expectations is expected; one much be able to 'construe the position of the other' (Kelly 1955). - to understand it from the other's position and in the other's terms - in order to play a part in it which does not rest directly on the use or threat of force. This kind of insight is logically necessary if a 'we' which includes both parties to the dialogue is to have any useful meaning (Akerlof 2016). Where the agents of government and of commerce cannot be trusted to stay 'in role', to see themselves as part of the nation rather than following their interests as individuals or in-group members and to act in the general interest rather than just their own, then country-wide mechanisms of governance become fragile and cease to establish unity in the nation. Corruption as a perceived norm among officials and functionaries sends signals about what sort of 'game' is being played (Rothstein 2011) which are inimical to social cohesion as a socio-political discourse at the level of the nation-state. A fully decent society (Abbott et al. 2016) is one which works in the interests of all its members and can be trusted to do so, and this is what social cohesion both expresses and ensures.

\section{Discussion and Conclusions}

Corruption is a social ill to which the MENA countries are gravely prone, and it ranks with economic and political issues as a cause for concern and a target of protest among survey respondents in the Arab Transformations survey and others carried out in the same area at around the same period. Indeed, it forms an important part of the set of problems against which people protested in 2011 and which were still seen as problems in 2014. Its overall result goes beyond particular politicals and/or economic issues, however, to damage both the inclusion of citizens and the social cohesion of norms and expectations which create a decent, shared society out of individuals, families and communities. We could identify linear causal chains from the existence of corruption to the particular damage done, but the process is better seen as numinous, recursive and multi-directional, because the 'cohesion/inclusion' complex is not just a set of descriptive facts about a society but a way of viewing social life and its predictabilities, responsibilities and reasonable expectations. What is at stake is (a)what people, groups and institutions see as their stake in the political process (inclusion) and (b) what they judge to be reasonable behaviour, in the light of their understanding of others and their predictions and hopes for how they will behave and react (the discourse of cohesion). Sometimes this discourse or world-view will be describable in words, but the words do not constitute its essence; it is constituted by people's lived experience of how things are done.

In economic terms, bribery is a tax on business and therefore a counter-redistributive tax on consumers, and in the form of payment for what are declared to be free services such as health and education it can have an impact on every family among those not well enough off to pay for private provision; in the case of health the need is often sudden and unexpected rather than planned and anticipated. In political terms this economic process establishes a disjuncture between those who extort bribes and those who pay them, which is a form of social exclusion (even if a given extorter may also be 
liable in a different context to face extortion). The process (a) divides the nation, in a given situation, in terms of power to control one's life and ability to plan for the future, (b) undermines the sense of empowerment which is needed for free development of capabilities, and (c) alienates people from their government and each other - destroys trust - and so weakens their perception of themselves as part of a unified society with shared interests. Differences become divisions, and debate becomes dissent. In most of the MENA countries we have studied here, the failure of social inclusion has persisted despite the uprisings, perhaps worsened by the momentary hope for something better.

Politically, the existence of groups which have grievances threatens social cohesion - it could, literally, split the nation - but it is less likely to do so if reliable mechanisms exist for dispute-resolution which are seen as fair to and by all parties. In a small grouping it is possible to resolve disputes at the level of persons or families, with the quality of the resolution being warranted by personal knowledge of the participants and their history; we have spoken, above, about the retreat from the public sphere into family and locality in an attempt to establish firm common ground, when the stranger cannot be trusted, and the pattern of who is trusted in the survey data shows some degree of compatibility with such a retreat. At the level of even a relatively small nation state there are too many people involved for this to be an effective organising principle for the state as a whole. We therefore depend on what we might call the 'myth' (or 'shared story') of the Rule of Law. The Rule of Law is seen as impersonal rather than personal; at its most effective, it transforms people with problems and interests into the personification (or perhaps 'impersonation'?) of social roles. The judge, the policeman, the civil servant, the legislator, and indeed the teacher, the doctor and even the postman will be individuals and members of groups, with their own and their group's powers, goals and characteristic ways of seeing the social world. In their public lives and when adopting these roles, however, they are supposed to put all that aside, follow the rules and the goals appropriate to their public role and try to set their own and the other party's way of seeing the world within the ontology associated with that role. (The same is true in the private sphere, with individuals who have their own whims and desires required to put them aside as e.g. 'mothers' and 'fathers' and behave appropriately to their role.)

Underneath the roles is the ideology or discourse which is fundamental for the social cohesion of something as large and impersonal as the nation state. At a local level our trust in the 'anonymous other', that he or she or they (the roles may not be personified) will see a duty to 'play fair' and do their best to perform it, is what gives us faith enough in the future to plan and invest without personal guarantees. Other parties can be trusted to do their best to understand our point of view, and their doing so imposes a duty on us to try to understand their position and gives us faith that there is some point in doing so. 'Us and them' becomes 'we' by this mechanism (Akerlof 2016) - as in 'despite our diversity we are agreed that the best course of action would be ...'. This is important when things do become impersonal - not 'people I know' or even 'people I could know in principle, if they came here', but people symbolising the social institutions they represent and by which they are constituted - courts, the law, the police, legislators, the education system, the health system, banking, commerce. Even with frequent lapses from this standard, the fact that it is acknowledged as an ideal is sufficient to hold things together provided that it is applied in practice fairly often. (See also Sapsford et al. 2017.)

This analysis has relevance far beyond just the MENA region, of course. Corruption is rife across most of sub-Saharan Africa and in Asia, to the detriment of trust in 
government and the reproduction of social cohesion. The corruption levels shown by Transparency International are worse in Italy and Greece than in Jordan, for example. Transparency International's website launches the 2017 Corruption Perception Index with the comment that there are no countries without corruption. In the 2013 report of their Global Corruption Barometer, based on pooled data from 2003 to 2013 (Transparency International 2013), they show Lithuania and Slovenia as having more than $25 \%$ who see bribery by individuals and companies as very high and Greece, Latvia, Hungary and Cyprus at around 30\%; similar European countries are included among the high scorers for corruption of politicians, with Lithuania at over $40 \%$ and Italy, Poland and Cyprus at more than 30\%. What people need everywhere, as a precondition for being empowered to develop and use their capabilities, is a world where 'we' can rely on each other under the Rule of Law, because the Rule of Law is not personalised but impersonal and institutional. If most people can be trusted to be fair with each other and the functionaries can be trusted to work lawfully and impartially rather than (or at least more than) to their own advantage, then we do not need to fear oppression or unequal material disadvantage and can 'go about our business'. (We should note that this is not necessarily as individualistic as it sounds; not everywhere in the world is as resolutely individualist 'at the point of consumption' as Great Britain and North America, and in most places people would talk about 'our' freedoms, the freedoms available to a group or class or community, as much as or more than the freedom of the individual. However, we should also remember that group identity can work against the national institutionalisation of law and fairness, particularly where a group or tribe or community has a collective identity forced on them through their perception of shared disadvantage or discrimination.)

'At the point of production', where governments operate with and on those they govern, such freedoms and such a lifestyle can be established, maintained and sustained only through the establishment of institutions, both concrete - families, commercial/ industrial concerns, bureaucracies - and discursive - shared expectations, conscience collective, visions for the future, hopes for the children. This is where behaviourally and intentionally defined variables such as trust and mutual understanding become aspects of an architecture of social relations. Corruption and wasta are part of the normal experience in the MENA countries we studied, and the detestation respondents express for them represents the extent to which they are not resigned to them but prepared to fight back again if need be. Where the behaviour of the powerful - whether members of an elite or those with a small and temporary power (e.g. a foreman on a building site) is blatantly aimed at the advantage of self or in-group, they are discarding the view of the social world as belonging in some sense to all parties; the powerful are not 'we' but 'them', at all levels of power, and it is exercised through coercion rather than consent. The evidence suggests that governments that are not responsive to the expressed needs and wishes of their people do eventually fail (Acemoglu and Robinson 2013).

Acknowledgements This article is based mainly on a survey funded by the European Union under the FP7 framework, Grant No. 320214. An earlier version appeared as one of Aberdeen University's Arab Transformations Working Papers (Sapsford et al. 2016). We are grateful to Viola Sanelli and Ilia Xypolia, at the University of Aberdeen, for material they supplied on the history and politics of the region.

The authors alone remain responsible for the content of the article. It does not necessarily represent the views of the EU, the Court of the University of Aberdeen or any of the ArabTrans project partners. 


\section{Compliance with Ethical Standards}

Ethics Statement The survey on which this article is mostly based was subject to the normal ethical procedures for public attitude surveys: oral informed consent was obtained, confidentiality was promised, participants were free to withdraw (and to withdraw their data) at any time, and material was stored in such a way as to prevent 'linkage' and the identification of participants by outside parties. The project obtained ethics approval from the Research Ethics Committee of the University of Aberdeen, the lead partner, and country partners obtained the permission of government or other agencies in their country where this was required.

Conflict of Interest None of the authors is aware of any conflict of interest.

Open Access This article is distributed under the terms of the Creative Commons Attribution 4.0 International License (http://creativecommons.org/licenses/by/4.0/), which permits unrestricted use, distribution, and reproduction in any medium, provided you give appropriate credit to the original author(s) and the source, provide a link to the Creative Commons license, and indicate if changes were made.

\section{References}

\section{Surveys and Databases}

AfroBarometer Round 6 (2015). African Barometer: http://afrobarometer.org/data.

Arab Barometer Wave 3 (2017). Arab Barometer: http://arabbarometer.org/instruments-and-data-files.

Arab Transformations Survey 2014. (2017). University of Aberdeen: http://www.arabtrans.eu.

Corruption Perception Index. (2017). Transparency International: http://www.transparency.org. uk/corruption/measuring-corruption/.

Enterprise Surveys. (2017). World Bank: http://www.enterprisesurveys.org.

Illicit Financial Flows. (2017). Global Financial Integrity: http://www.gfintegrity.org/report/illicit-financialflows-from-developing-countries-2004-2013/.

\section{Other References}

Abbott, P., Sapsford, R., Díez-Nicolás, J., \& Teti, A. (2017). The Arab Transformations project manual. University of Aberdeen, Arab Transformations Research Project. http://www.arabtrans.eu.

Abbott, P., \& Teti, A. (Eds) (2016). The Arab Transformations project: political, and social changes in Morocco, Algeria, Tunisia, Libya, Egypt, Jordan and Iraq. University of Aberdeen, Arab Transformations Project. https://doi.org/10.13140/RG.2.2.15194.95688 .

Abbott, P., \& Teti, A. (2017). Political, social and economic drivers of the 2011 Egyptian uprising. University of Aberdeen, Arab Transformations research project, Arab Transformations Working Paper 6. https://doi. org/10.13140/RG.2.2.26580.81286.

Abbott, P., Wallace, C., \& Sapsford, R. (2016). The decent society: Planning for social quality. London: Routledge.

Acemoglu, D., \& Robinson, J. A. (2013). Why nations fail. London: Profile Books.

Akerlof, G. (2016). We-thinking' and its consequences. American Economic Review, 106(5), 415-419. https://doi.org/10.1257/aer.p20161040.

Almond, G., \& Verba, S. (1963). The civic culture: Political attitudes and democracy in five nations. Princeton: Princeton University Press. https://doi.org/10.1515/9781400874569.

Anderson, C. J., \& Tverdova, Y. V. (2003). Corruption, political allegiances, and attitudes toward government in contemporary democracies. American Journal of Political Science, 47(1), 91-109. https://doi. org/10.1111/1540-5907.00007.

Bellin, E. R. (2002). Stalled democracy: Capital, labor, and the paradox of state-sponsored development. Ithaca: Cornell University Press. 
Beschel, R. (2008). Corruption in the MENA region: A declining trend or more of the same? Washington: World Bank, Site Resources http://siteresources. Worldbank. org/INTMNAREGTOPGOVERNANCE/Resources/corruptioninmena.pdf.

Booth, D., \& Golooba-Mutebi, F. (2012). Developmental patrimonialism? The case of Rwanda. African Affairs, 111(444), 379-403. https://doi.org/10.1093/afraf/ads026.

Durkheim, E. (1893). De la Division du Travail Social. English edition: The Division of Labour in Society, translated by W. Halls, edited by S. Lukes. New York: Simon and Schuster.

El Atiyas, I. (2014). Enhancing competition in a post-revolutionary Aran context. In I. Diwan (Ed.), Understanding the political economy of the Arab uprisings. Singapore: World Scientific Publishing. https://doi.org/10.1142/9789814596015 0008.

Habib, M., \& Zurawicki, L. (2002). Corruuption and foreign direct investment. Journal of the Institute of Business Studies, 33(2), 291-307. https://doi.org/10.1057/palgrave.jibs.8491017.

Hanieh, A. (2013). Lineages of revolt. Chicago: Haymarket Books.

Heath, A., Richards, L., \& de Graaf, N. (2016). Explaining corruption in the developed wortld: The potential of sociological approaches. Annual Review of Sociology, 42(1), 51-79. https://doi.org/10.1146/annurevsoc-081715-074213.

Kaärinen, J. (2007). Trust in the police in 16 European countries.: A multi-level analysis. European Journal of Criminology, 4(4), 409-435. https://doi.org/10.1177/1477370807080720.

Kelly, G. A. (1955). The psychology of personal constructs, vol. 1. New York: Norton.

Raiser, M. (1998). Trust in transition. In Paper given at a conference on Post-Communist Transformations and the Social Sciences: cross disciplinary approaches. Berlin, October.

Richards, A., Waterbury, J., Cammett, M., \& Ciwan, I. (2014). A political economy of the Middle East. Boulder: Westview Press.

Rothstein, B. (2011). The quality of government: Corruption, social trust and inequality in international perspective. Chicago: University of Chicago Press. https://doi.org/10.7208 /chicago/9780226729589.001.0001.

Sapsford, R., Abbott, P., Haerpfer, C., \& Wallace, C. (2015). Trust in Post-Soviet Countries, ten years on. European Politics and Society, 16(4), 523-539. https://doi.org/10.1080/23745118.2015.1039286.

Sapsford, R., Abbott, P., \& Teti, A. (2017). The integrity of states: corruption in the EU's southern neighbourhood. University of Aberdeen, Arab Transformations Research Project, Arab Transformations Policy Brief No. 6.

Sapsford R., Tsourapas, G., \& Abbott, P. (2016). Corruption, cohesion and the rule of law. University of Aberdeen, Arab Transformations Research Project, Arab Transformations Working Paper 15.

Seligson, M. A. (2002). The impact of corruption on regime legitimacy: a comparative study of four Latin American countries. The Journal of Politics, 64(2), 408-433. https://doi.org/10.1111/1468-2508.00132.

Sztompka, P. (1999). Trust: A sociological theory. Cambridge: Cambridge University Press.

Transparency International. (2013). Global corruption barometer 2003-2013. Berlin: Transparency International.

You, J.-S., \& Khagram, S. (2005). A comparative study of inequality and corruption. American Sociological Review, 70, 136-157. 